\title{
Modulation of Interleukin-1 $\beta$ and Tumor Necrosis Factor $\alpha$ Signaling by P2 Purinergic Receptors in Human Fetal Astrocytes
}

\author{
Judy S. H. Liu, ${ }^{1}$ Gareth R. John, ${ }^{1}$ Andrew Sikora, ${ }^{2}$ Sunhee C. Lee, ${ }^{1}$ and Celia F. Brosnan ${ }^{1,3}$ \\ Departments of ${ }^{1}$ Pathology, ${ }^{2}$ Microbiology and Immunology, and ${ }^{3}$ Neuroscience, Albert Einstein College of Medicine, \\ Bronx, New York 10461
}

\begin{abstract}
In human astrocytes, interleukin- $1 \beta(\mathrm{IL}-1 \beta)$ is a potent inducer of genes associated with inflammation. In this study, we tested the hypothesis that in primary cultures of human fetal astrocytes signaling by the P2 purinergic nucleotide receptor pathway contributes to, or modulates, cytokine-mediated signal transduction. Calcium imaging studies indicated that most cells in culture responded to ATP, whereas only a subpopulation responded to UTP. Pretreatment of astrocytes with P2 receptor antagonists, including suramin and periodate oxidized ATP (oATP), resulted in a significant downregulation of IL- $1 \beta$-stimulated expression of nitric oxide, tumor necrosis factor (TNF $\alpha$ ), and IL-6 at both the protein and mRNA levels, without affecting cell viability. In cells transiently transfected with reporter constructs, IL-1 $\beta$ demonstrated more potent activation of the transcription factors nuclear factor $-\kappa \mathrm{B}(\mathrm{NF}-\kappa \mathrm{B})$ and activator protein-1 (AP-1) than TNF $\alpha$. However, pretreatment with OATP downregulated activation of
\end{abstract}

$\mathrm{NF}-\kappa \mathrm{B}$ and $\mathrm{AP}-1$ by IL- $1 \beta$ or $\mathrm{TNF} \alpha$. Electromobility shift assays using oligonucleotides containing specific NF- $\kappa$ B binding sequences confirmed that pretreatment with oATP or apyrase attenuated cytokine-mediated induction of this transcription factor. From these data, we conclude that $\mathrm{P} 2$ receptor-mediated signaling intersects with that of IL- $1 \beta$ and TNF $\alpha$ to regulate responses to cytokines in the CNS. Because inflammation, trauma, and stress all lead to the release of high levels of extracellular nucleotides, such as ATP and UTP, signaling via P2 receptors may provide a mechanism whereby cells can sense and respond to events occurring in the extracellular environment and can fine tune the transcription of genes involved in the inflammatory response.

Key words: $P 2$ receptors; IL-1 $\beta$; TNF $\alpha$; human fetal astrocytes; transcription factor $N F-\kappa B$; transcription factor $A P-1$
Astrocytes maintain the homeostatic environment of the CNS and play an important role in regulation of immune responses by functioning as a source of proinflammatory cytokines, chemokines, and immune effector molecules (Ransom and Sontheimer, 1992; Norenberg, 1997). Astrocytic processes envelop neurons and form a glial limitans at the subpial surface and around the vasculature. Imaging studies have shown that these cells are interconnected by at least two distinct pathways: an intercellular pathway mediated by gap junctions and an extracellular pathway mediated by P2 purinergic receptors that respond to nucleotides such as ATP (Guthrie et al., 1999). Regulation of these properties of astrocytes in various disease states may therefore represent an important component of the maintenance of appropriate neuronal function.

The cytokine IL- $1 \beta$ acts on human astrocytes to induce expression of multiple genes associated with inflammation, such as interleukin-6, tumor necrosis factor- $\alpha(\mathrm{TNF} \alpha)$, and the inducible form of nitric oxide synthase (NOS II) (Lee et al., 1993a,b), as well inducing a reorganization of the cytoskeleton, resulting in a shape change (stellation) resembling a reactive gliosis (Liu et al., 1994). Recently, we showed that treatment of human astrocytes with IL- $1 \beta$ also profoundly affected astrocyte communication pathways, resulting in an uncoupling of gap junctions and, conversely, an upregulation of P2 receptor-mediated signaling (John et al., 1999). Because events such as mechanical stress, trauma, and inflammation all lead to the release of high levels of extracellular nucleotides, the ability to detect changes in the source and local concentration of these molecules may provide the cell with important

Received Sept. 22, 1999; revised April 18, 2000; accepted April 26, 2000.

This work was supported by National Multiple Sclerosis Society Grant RG2771 and United States Public Health Service Grants NS11920, MH55477, and T32GMO7288. We thank Dr. Karen Weidenheim, Director of the Human Fetal Tissue Repository, for tissue collection. We also thank David Spray and Eliana Scemes for help with the calcium imaging, and Meng-Liang Zhao and Wa Shen for culture preparation.

Correspondence should be addressed to Dr. Celia F. Brosnan, Department of Pathology, Albert Einstein College of Medicine, 1300 Morris Park Avenue, Bronx, NY 10461. E-mail: brosnan@aecom.yu.edu.

Copyright (C) 2000 Society for Neuroscience $0270-6474 / 00 / 205292-08 \$ 15.00 / 0$ information about events occurring in the extracellular environment. Most cell types express both P1 and P2 type receptors, and signaling via these receptors modulates many biological effects, including neurotransmission, inflammation, and immune-mediated reactivity (Dubyak and el-Moatassim, 1993; DiVirgilio, 1995; Burnstock, 1997). Astrocytes express predominantly members of the metabotropic P2Y receptor family, which are seven transmembrane-spanning receptors coupled to G-proteins (King et al., 1996; Centemeri et al., 1997). P2 $Y_{1}$, a member of the P2 family of receptors, has been shown recently to mediate calcium wave propagation in rat astrocyte cultures derived from dorsal spinal cord (Fam et al., 2000).

In this study, we tested the hypothesis that autocrine/paracrine signaling via $\mathrm{P} 2$ receptors modulates the response of astrocytes to IL- $1 \beta$. Binding of IL- $1 \beta$ drives dimerization of the IL- 1 receptor type 1 with its accessory protein, followed by the recruitment and phosphorylation of the receptor associated kinases (IRAK1 and IRAK2) via MyD88. IRAK-1 subsequently interacts with TNF receptor-associated factor-6, followed by phosphorylation of nuclear factor- $\kappa \mathrm{B}(\mathrm{NF}-\kappa \mathrm{B})$-inducing kinase, which is a mitogenactivated protein (MAP) kinase kinase kinase that phosphorylates and activates the $\mathrm{I} \kappa \mathrm{B}$ kinases, resulting in the translocation of $\mathrm{NF}-\kappa \mathrm{B}$ to the nucleus (Mercurio and Manning, 1999). IL-1 $\beta$ also activates a distinct MAP kinase cascade that results in DNA binding of activator protein-1 (AP-1) (Minden and Karin, 1997). $\mathrm{TNF} \alpha$ activates similar cascades, but cell-type and species-specific differences exist in the relative potency that these two cytokines display (Ghosh et al., 1998). We now show that autocrine/paracrine signaling via $\mathrm{P} 2$ receptors significantly modulates both IL- $1 \beta$ - and TNF $\alpha$-mediated activation of NF- $\kappa$ B and AP-1 in human fetal astrocytes, supporting a regulatory role for these receptors in inflammatory reactions in the human CNS.

\section{MATERIALS AND METHODS}

Astrocyte cultures and cytokines. Enriched human fetal brain astrocyte cultures were established from second trimester abortuses as described previously (Lee et al., 1992). Culture purity was determined by immuno- 
staining for glial fibrillary acidic protein (astrocytes), microtubuleassociated protein-2 (neurons), and CD68 (microglia). All tissue collection was approved by the Institutional Clinical Review Committee. Recombinant human IL-1 $\beta$ was a gift from the Biological Response Modifiers Program at the National Cancer Institute (Frederick, MD), and TNF $\alpha$ and interferon- $\gamma$ (IFN $\gamma$ ) were from Genzyme (Cambridge, MA).

Treatment of cell cultures with antagonists of purinergic receptors. Periodate oxidized ATP (oATP) (Sigma, St. Louis, MO), suramin (Calbiochem, San Diego, CA), and 8-(sulfophenyl) theophylline (SPX) (Sigma) were dissolved in DMEM and used at the concentrations indicated. Cells were pretreated for $2 \mathrm{hr}$ before cytokine stimulation. Medium was changed in both oATP-treated and control cultures immediately before addition of cytokines as indicated. All other inhibitors were left in the medium during cytokine treatment of cultures.

Calcium measurements. Astrocytes were plated on uncoated glassbottomed microwells (Mat-Tek, Ashland, MA) at a density of $2.5 \times 10^{5}$ cells $/ \mathrm{ml}$. At 7-30 d after plating, confluent cultures were loaded with $10 \mu \mathrm{M}$ Indo-1 AM (Molecular Probes, Eugene, OR) at $37^{\circ} \mathrm{C}$ for $45 \mathrm{~min}$ and rinsed in PBS, $\mathrm{pH} 7.4$, and the ratio of Indo-1 fluorescence intensity emitted at two wavelengths $(390-440$ and $>440 \mathrm{~nm})$ was imaged using UV laser excitation at $351 \mathrm{~nm}$ on a Nikon (Tokyo, Japan) RCM 8000 real-time confocal microscope. After background and shading correction with UV large pinhole and Nikon $40 \times$ water immersion objective (NA, 1.15; working distance, $0.2 \mathrm{~mm}$ ), Indo- 1 fluorescence ratio images were continuously acquired at $1 \mathrm{~Hz}$ before and after application of a chemical stimulus. The efficacy of calcium mobilization was calculated as the proportion of cells within the field responding with an increase in intracellular calcium concentration. Half-maximal calcium increases were obtained from sigmoida curves fitted to the ascending phase of each Indo-1 fluorescence ratio increase.

Detection of nitric oxide formation. After activation with cytokines, the levels of nitrite in the cell supernatant were measured at the times indicated by the Griess reaction as described previously (Lee et al., 1993b).

Northern blot analysis. At indicated times, total RNA was extracted by Trizol (Life Technologies, Gaithersburg, MD), and Northern blot analysis for type II NOS and IL-6 was performed as described previously (Lin et al., 1996, 1998). Human hepatocyte type II NOS cDNA was kindly provided by Dr D. Geller (University of Pittsburgh, Pittsburgh, PA), and human IL-6 cDNA was provided by Dr. T. Hirano (Osaka University Medical School, Osaka, Japan).

Cytokine ELISA. Astrocytes were cultured at 2-4 $\times 10^{4}$ cells per well in 96 well plates. Culture medium was changed at $0 \mathrm{hr}$, astrocytes were stimulated in triplicate by cytokines at doses indicated, supernatants were collected at $16 \mathrm{hr}$, and levels of TNF $\alpha$ and IL-6 in the supernatant was determined by ELISA (R \& D Systems, Minneapolis, MN; Immunotech, Westbrook, ME)

Transient transfection of astrocytes and reporter gene activity. Cultures of primary human astrocytes were transfected using Lipofectamine (Life Technologies). Briefly, $1 \mu \mathrm{g}$ of the NF- $\kappa \mathrm{B}$-luciferase reporter construct $\mathrm{pIg}$ $\kappa$-Luc (Fujita et al., 1993) or AP-1 reporter construct 6AP-1-luc (gift from Roya Khosravi-Far, Harvard Medical School, Boston, MA) and $10 \mu \mathrm{l}$ of lipofectamine were incubated for $30 \mathrm{~min}$ in $200 \mu \mathrm{l}$ of serum- and antibioticfree medium to form DNA liposome complexes. Astrocytes in six well plates $(80 \%$ confluent) were incubated with the transfection mix for $5 \mathrm{hr}$ and then transferred to medium containing 5\% FBS. Eighteen hours later, cells were treated with the indicated agents for $6 \mathrm{hr}$ and harvested with 300 $\mu l$ of reporter lysis buffer (Promega, Madison, WI). Twenty microliters of lysate were added to $100 \mu \mathrm{l}$ of luciferase substrate (Promega) for $7 \mathrm{sec}$, and relative light units (RLU) were determined (Lumat LB luminometer; Berthold, Bad Wildbad, Germany). In preliminary experiments, $0.3 \mu \mathrm{g}$ of cytomegalovirus (CMV)- $\beta$-galactosidase (Promega) was cotransfected with reporter constructs to control for differences in transfection efficiency between wells; however, it was found that cytokine simulation consistently upregulated $\mathrm{CMV}$-driven constructs and that transfection efficiency did not differ between wells from the same cases plated at the same density. Percent reduction of IL- $1 \beta$-induced NF- $\kappa$ B induction was determined after subtraction of control values.

Electromobility shift assay. Astrocytes in $100 \mathrm{~mm}$ dishes were pretreated for $2 \mathrm{hr}$ with $300 \mu \mathrm{M}$ oATP, the medium was replaced, and cells were

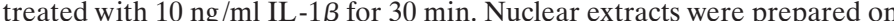
ice using a modified Dignam method (Akama et al., 1998). All buffers were supplemented with $1 \mathrm{~mm}$ PMSF, $1 \mathrm{~mm}$ DTT, and a cocktail of protease inhibitors (Boehringer Mannheim, Indianapolis, IN). Cells $\left(\sim 1 \times 10^{7}\right)$ were scraped into $1.2 \mathrm{ml}$ of $1 \mathrm{~mm}$ PMSF, calcium-magnesium free PBS, and pelleted in microcentrifuge tubes. Pellets were resuspended in low-salt buffer (10 mM HEPES, pH 7.9, $1.5 \mathrm{mM} \mathrm{MgCl}_{2}$, and $\left.10 \mathrm{~mm} \mathrm{KCl}\right)$ and allowed to sit on ice for $10 \mathrm{~min}$ before the addition of $75 \mu \mathrm{l}$ of $10 \%$ Nonidet $\mathrm{P}-40$. Samples were then vortexed for $10 \mathrm{sec}$ and spun at $13,000 \times \mathrm{g}$ for 30 sec. The nuclear pellet was then resuspended in high-salt buffer $(20 \mathrm{~mm}$ HEPES, pH 7.9, $25 \%$ glycerol, $420 \mathrm{~mm} \mathrm{NaCl}, 1.5 \mathrm{~mm} \mathrm{MgCl} 2$, and $0.2 \mathrm{~mm}$ EDTA) and allowed to rock gently at $4^{\circ} \mathrm{C}$ for $30 \mathrm{~min}$ before centrifugation for $15 \mathrm{~min}(13,000 \times \mathrm{g})$. Supernatants were collected, and protein content was determined using the Bradford assay.

An electromobility shift assay (EMSA) was performed using the Gel Shift Assay Core System (Promega) and $\gamma^{-32} \mathrm{P}$ labeled oligonucleotides containing the NF- $\kappa \mathrm{B}$ consensus binding sequence (5' AGT TGA GGG GAC TTT CCC AGG C-3'). Nuclear extracts $(4 \mu \mathrm{g})$ were incubated in
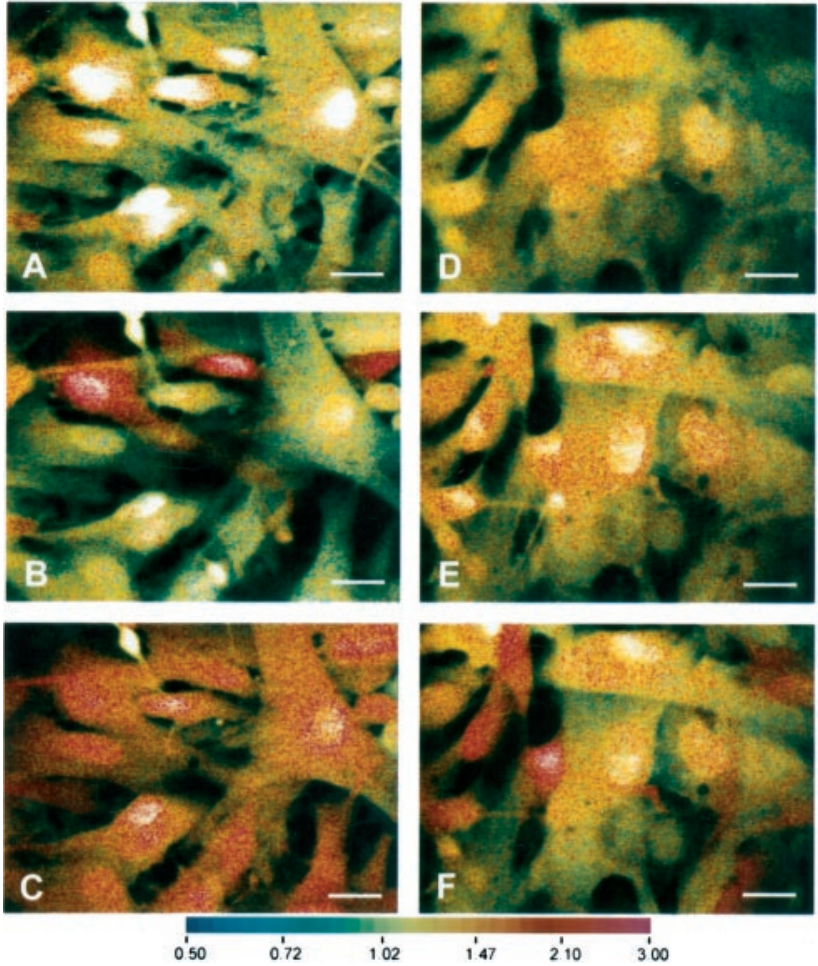

Figure 1. Exogenously added nucleotides results in transient elevations of intracellular calcium in human astrocytes that is blocked by oATP. Astrocytes were loaded with $10 \mu \mathrm{M}$ Indo- 1 for $45 \mathrm{~min}$ and visualized by real-time confocal imaging microscopy. Increase in intracellular calcium was visualized as a shift toward the red spectrum. $A-C$ show the same field without stimulation $(A)$ and after exposure to $100 \mu \mathrm{M} \operatorname{UTP}(B)$ or $100 \mu \mathrm{M} \operatorname{ATP}(C)$ $D-F$ are also of the same field in cultures pretreated with $300 \mu \mathrm{M}$ oATP, showing control no stimulation $(D)$ and $100 \mu \mathrm{M}$ UTP $(E)$ or $100 \mu \mathrm{M}$ ATP $(F)$. Note the similarity in basal intracellular calcium levels in control $(A)$ and oATP-treated $(D)$ cells. All panels of nucleotide-treated cultures are shown at mean peak intracellular calcium concentrations after treatments. The experiment shown is one of three, each on cells derived from different brains. Scale bars, $25 \mu \mathrm{m}$.

binding buffer [ $4 \%$ glycerol, $1 \mathrm{~mm} \mathrm{MgCl}, 0.5 \mathrm{~mm}$ EDTA, $50 \mathrm{~mm} \mathrm{NaCl}, 10$ $\mathrm{mm}$ Tris-HCl, and $50 \mu \mathrm{g} / \mathrm{ml}$ poly $(\mathrm{dI}-\mathrm{dC})]$ with $1.75 \mathrm{pmol}$ of either specific or mutant oligonucleotides (Santa Cruz Biotechnology, Santa Cruz, CA) or nonspecific competitor oligonucleotides for $15 \mathrm{~min}$ before addition of labeled probe. After incubation at room temperature for $20 \mathrm{~min}$, supershift antibodies ( $2 \mu \mathrm{g}$; Santa Cruz Biotechnology) were added for another 40 min. Samples were separated on a $5.5 \%$ polyacrylamide, $5 \%$ glycerol gel in Tris-glycine buffer.

Western blot analysis of NOS II protein expression. Cells were harvested $48 \mathrm{hr}$ after cytokine treatment, and NOS II protein expression was determined as described previously using an affinity-purified rabbit polyclonal antibody against human macrophage NOS II (1:1000; Transduction Laboratories, Lexington, KY).

Statistics. Statistical analysis was performed using Student's $t$ test or ANOVA. $p<0.05$ was considered significant.

\section{RESULTS}

\section{Characterization of calcium response to nucleotide triphosphates in cultures of primary human fetal astrocytes}

Human fetal astrocyte cultures loaded with Indo-1 AM were subjected to laser confocal microscopy to determine the response of these cells to the nucleotide triphosphates UTP and ATP. The cells were first challenged with UTP $(100 \mu \mathrm{M})$. Approximately $30 \%$ responded with an increase in intracellular calcium concentration (Fig. 1, compare $A, B$ ). The cells were then washed. When intracellular calcium had returned to baseline levels, the same cells were challenged with ATP $(100 \mu \mathrm{M})$; as demonstrated in $C$, all astrocytes responded with a marked increase in intracellular calcium. These results indicated that the population of cells within these primary cultures was heterogeneous and that although, human fetal astrocytes responded to ATP, a proportion also expressed a receptor 


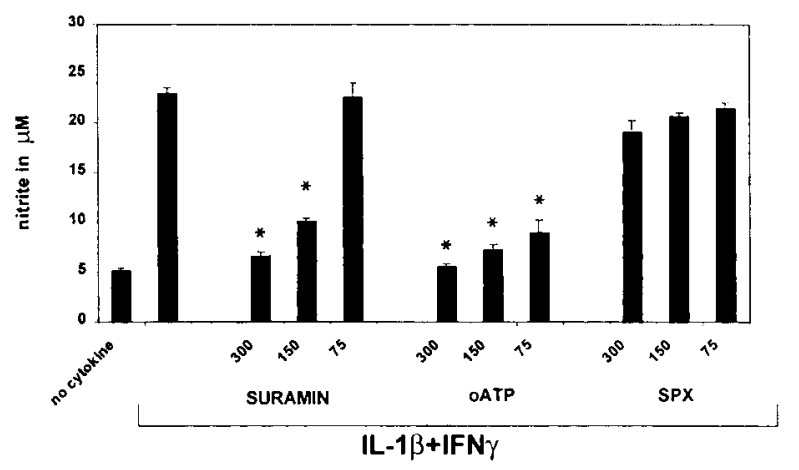

Figure 2. Blockade of $\mathrm{P} 2$ receptors on astrocytes downregulates nitrite production. Astrocytes were pretreated for $2 \mathrm{hr}$ with the inhibitors oATP suramin, and SPX, at concentrations of 300,150 , and $75 \mu \mathrm{M}$. OATP was washed out before the addition of IL-1 $\beta(10 \mathrm{ng} / \mathrm{ml})$ plus IFN $\gamma(200 \mathrm{U} / \mathrm{ml})$. Nitrite was determined at $48 \mathrm{hr}$. The P2 inhibitors oATP and suramin demonstrated a dose-dependent inhibition of nitrite production. In contrast, the P1 inhibitor SPX had no effect. ${ }^{*} p<0.05$ indicates statistically significant reduction of nitrite compared with cytokine stimulation without inhibitors. Data represent the mean and SD of astrocytes from five different wells per data point and are representative of four separate experiments on cells derived from different brains.

that responded to UTP. To determine whether the responses could be blocked by $\mathrm{P} 2$ receptor antagonists, astrocyte cultures were pretreated with oATP for $2 \mathrm{hr}(300 \mu \mathrm{M})(D-F)$. The chemical structure of oATP and its affinity for a wide range of ATP binding proteins suggests that it would interact with a number of P2 receptor subtypes. The cells were then challenged with UTP $(E)$ or $\operatorname{ATP}(F)$, and their responses were compared with those of control untreated cultures. The rise in intracellular calcium stimulated by $100 \mu \mathrm{M}$ UTP was completely blocked by oATP, whereas the response to $100 \mu \mathrm{M}$ ATP was blocked in $\sim 55 \%$ of cells by oATP.

\section{Blockade of $\mathrm{P} 2$ receptors on astrocytes downregulates nitrite production}

In previous studies, we showed that the expression of type II NOS in human fetal astrocytes was critically dependent on activation with IL-1 $\beta$, with IFN $\gamma$ acting synergistically (Lee et al., 1993b; Liu et al., 1996). To determine whether signaling via the $\mathrm{P} 2$ receptor pathway modulated NOS II expression, astrocytes were pretreated with a panel of $\mathrm{P} 2$ receptor antagonists for $2 \mathrm{hr}$ and then stimulated with IL-1 $\beta(10 \mathrm{ng} / \mathrm{ml})$ plus IFN $\gamma(200 \mathrm{U} / \mathrm{ml})$, and nitrite levels in the cell supernatant were measured at $48 \mathrm{hr}$ (Fig. 2). Pretreatment of the cells with the classical P2 receptor antagonist suramin or oATP resulted in a significant dose-dependent downregulation of nitrite production, with oATP demonstrating greater inhibition than suramin at the lowest doses tested $(75-300 \mu \mathrm{M})$. A similar effect was noted with pyridoxalphosphate-6-azophenyl-2', 4'disulfonic acid (data not shown). In contrast, the P1 receptor antagonist SPX had no effect, indicating no role for P1 receptors that preferentially bind adenosine or AMP but not ADP or ATP. None of the inhibitors when given alone affected nitrite production, and none of the inhibitors was toxic for the cells, as determined by lactate dehydrogenase release or trypan blue exclusion (data not shown). These data suggested that ATP was present in the culture medium, and this was confirmed using an assay for the conversion of luciferin to luciferase, a reaction that requires ATP. Medium from astrocyte cultures had 10,713 $\pm 1387 \mathrm{RLU}(\sim 0.4 \mu \mathrm{M})$ in contrast to unconditioned medium, $2217 \pm 303 \mathrm{RLU}(\sim 0.05 \mu \mathrm{M})$. Because blockade of P2 receptors by oATP has been shown to be irreversible (Murgia et al., 1993), it was used for all subsequent experiments and washed out of the medium before cytokine exposure.

\section{Blockade of $\mathrm{P} 2$ receptors on astrocytes downregulates induction of TNF $\alpha$ and IL-6}

To determine whether antagonism of $\mathrm{P} 2$ receptors affected the expression of other genes activated in astrocytes by IL- $1 \beta$, the cells

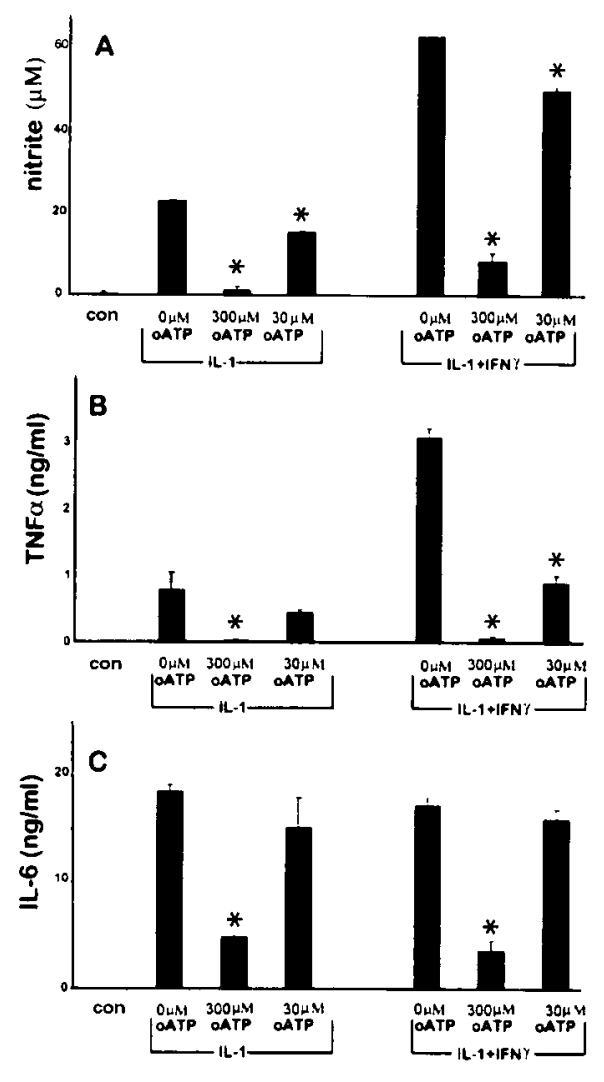

Figure 3. Blockade of $\mathrm{P} 2$ receptors on astrocytes downregulates induction of $\mathrm{TNF} \alpha$, IL-6, and nitrite production. Astrocytes were pretreated with varying doses of oATP $(0,300$, or $30 \mu \mathrm{M})$ for $2 \mathrm{hr}$, washed, and exposed to IL- $1 \beta(10 \mathrm{ng} / \mathrm{ml})$ or IL- $1 \beta$ plus IFN $\gamma(200 \mathrm{U} / \mathrm{ml})$ as indicated. Control cultures (con) consisted of astrocytes treated with oATP alone $(300 \mu \mathrm{M})$ without cytokines. TNF $\alpha(B)$ and IL-6 $(C)$ levels in the supernatant were determined at $16 \mathrm{hr}$ and nitrite $(A)$ at $48 \mathrm{hr}$. Pretreatment with oATP resulted in a dose-dependent inhibition of nitrite, TNF $\alpha$, and IL-6 after stimulation with IL $-1 \beta$ alone or in combination with IFN $\gamma$. Note also that, whereas IFN $\gamma$ potently synergized with IL $-1 \beta$ for nitrite and TNF $\alpha$ production, it had little effect on IL-6 expression. ${ }^{*} p<0.05$ indicates statistically significant reduction compared with cytokine stimulation without inhibitors. Data represent the mean and SD of results from three different wells and are representative of cells derived from three different brains.

were pretreated with oATP, washed, and activated with either IL-1 $\beta$ (10 ng/ml) alone or IL- $1 \beta$ plus IFN $\gamma(200 \mathrm{U} / \mathrm{ml})$. After incubation for $16 \mathrm{hr}$, the levels of TNF $\alpha$ and IL-6 in the supernatant were determined by ELISA, and nitrite production was measured at $48 \mathrm{hr}$ (Fig. 3). Consistent with previous data (Lee et al., 1993b; Liu et al., 1996), IFN $\gamma$ synergized with IL-1 $\beta$ in the induction of NOS II and TNF $\alpha$ in these cells, whereas the production of IL- 6 was not augmented by costimulation with IFN $\gamma$. Pretreatment with oATP resulted in a dose-dependent inhibition of the production of nitrite, TNF $\alpha$, and IL-6 in samples stimulated by either IL- $1 \beta$ alone or IL- $1 \beta$ plus IFN $\gamma$.

\section{Inhibition of astrocyte $\mathrm{P} 2$ receptors results in inhibition} of NOS II, TNF $\alpha$, and IL-6 mRNA accumulation

Cytokines regulate the production of nitrite by transcriptional activation of the NOS II gene. To test whether pretreatment with oATP downregulated IL- $1 \beta$-induced gene expression in these cultures, the levels of mRNA for TNF $\alpha$, IL-6, and NOS II were determined by Northern blotting. Astrocyte cultures were treated as described above, and RNA was harvested at $6 \mathrm{hr}$ for the determination of TNF $\alpha$ mRNA and at $24 \mathrm{hr}$ for the determination of both IL-6 and NOS II mRNA, time points that we have shown previously represent peak levels of gene expression after activation with IL-1 $\beta$ (Liu et al., 1996). Pretreatment with oATP led to a dose-dependent reduction in mRNA expression for NOS II and IL-6 (Fig. 4A) and TNF $\alpha$ (data not shown), in cultures activated 
A

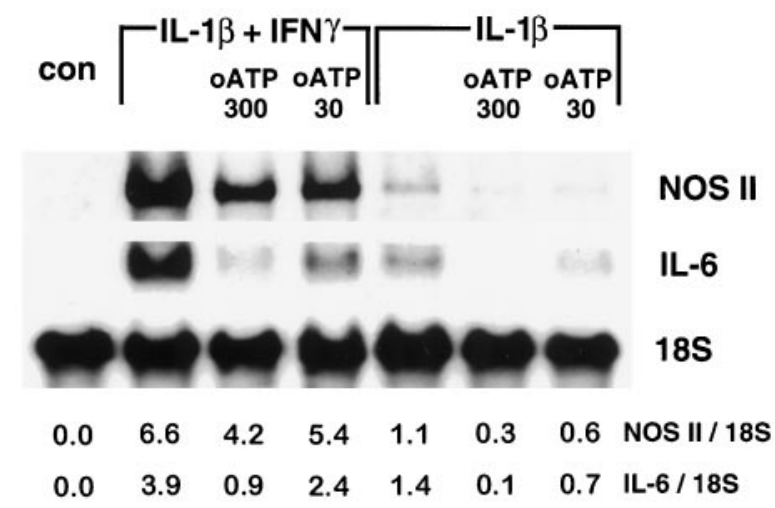

B

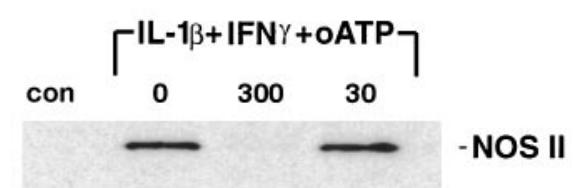

Figure 4. Blockade of astrocyte $\mathrm{P} 2$ receptors results in inhibition of NOS II, and IL- 6 mRNA and NOS II protein expression. $A$, RNA was extracted $24 \mathrm{hr}$ after cytokine treatment from the same cultures described in Figure 3 and subjected to Northern analysis of NOS II, IL-6, and 18 S mRNA $(A)$. Densitometric ratios of NOS II and IL-6 to 18 S are given below each lane. The results show that $\mathrm{P} 2$ blockade acts at the level of mRNA expression. Data shown are representative of three separate experiments on cells derived from three different brains. $B$, NOS II protein expression was determined by Western blot analysis of homogenates. Astrocytes were pretreated with 0,30 , or $300 \mu \mathrm{M}$ oATP for $2 \mathrm{hr}$, washed, and treated with IL- $1 \beta(10 \mathrm{ng} / \mathrm{ml})$ plus IFN $\gamma(200 \mathrm{U} / \mathrm{ml})$ for $48 \mathrm{hr}$. Cytokine stimulation resulted in strong induction of NOS II (130 kDa band) that was markedly reduced in cells that had been pretreated with $300 \mu \mathrm{M}$ oATP. Data shown are representative of four independent experiments.

with either IL- $1 \beta$ or IL- $1 \beta$ plus IFN $\gamma$. These data indicate that pretreatment with oATP blocked IL- $1 \beta$-induced expression of these genes by inhibiting the accumulation of specific mRNAs in the cell. Western blotting of cellular homogenates from these cultures confirmed that pretreatment with oATP led to an inhibition of cytokine-induced expression of NOS II protein (Fig. 4B). From these data, we conclude that antagonism of the $\mathrm{P} 2$ receptor downregulated the expression of multiple genes induced in human fetal astrocytes by IL-1.

\section{IL-1 $\beta$ and TNF $\alpha$ induction of NF- $\kappa$ B transcriptional activation is dose-dependent and downregulated by OATP}

Because oATP pretreatment resulted in inhibition of three IL- $1 \beta$ inducible proteins NOS II, TNF $\alpha$, and IL-6, we hypothesized that blockade of $\mathrm{P} 2$ receptors modulated the IL- $1 \beta$ signal transduction cascade. In most cell types, binding of IL- $1 \beta$ to the type I receptor activates the acute phase transcription factor $\mathrm{NF}-\kappa \mathrm{B}$, which is an inducible enhancer of many inflammatory genes, including NOS II (Marks-Konczalik et al., 1998; Taylor et al., 1998; Mercurio and Manning, 1999). TNF $\alpha$ is also a potent activator of NF- $\kappa \mathrm{B}$, and the signaling pathways activated by IL $-1 \beta$ and $\mathrm{TNF} \alpha$ are thought to converge at the level of the NF- $\kappa \mathrm{B}$ inducing kinase (Ghosh et al., 1998). However, in contrast to IL- $1 \beta, \mathrm{TNF} \alpha$ does not lead to the activation of NOS II expression in human fetal astrocytes and only minimally synergizes with IL- $1 \beta$ and IFN $\gamma$ in NOS II expression (Liu et al., 1996). To compare the level of activation of NF- $\kappa \mathrm{B}$ by IL- $1 \beta$ and TNF $\alpha$ in human fetal astrocytes, we transiently transfected cells with the NF- $\kappa \mathrm{B}$-dependent reporter Ig $\kappa$-Luc, stimulated the cells with three different doses of IL $-1 \beta$ and $\mathrm{TNF} \alpha$, and measured luciferase activity after $6 \mathrm{hr}$. Both IL-1 $\beta$ and TNF $\alpha$ treatment resulted in a dose-dependent induction of $\mathrm{NF}-\kappa \mathrm{B}$, but
A

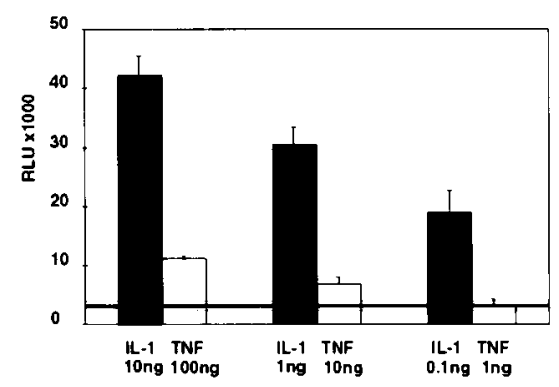

B

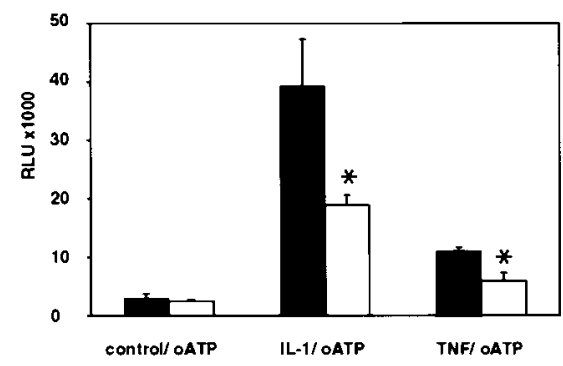

Figure 5. IL-1 $\beta$ and TNF $\alpha$ activation of NF- $\kappa \mathrm{B}$ is dose-dependent and downregulated by $\mathrm{P} 2$ receptor blockade. $A$, Astrocyte cultures were transiently transfected with a reporter construct for NF- $\kappa$ B activity. Cells were treated with either IL- $1 \beta(0.1,1$, or $10 \mathrm{ng} / \mathrm{ml})$ or $\mathrm{TNF} \alpha(1,10$, or 100 $\mathrm{ng} / \mathrm{ml})$, and luciferase activity was measured at $5 \mathrm{hr}(A)$. Level of luciferase activity (expressed as RLU) in untreated cells is represented by the transverse line, and SDs of these background levels are demarcated by the dotted lines. NF- $\kappa \mathrm{B}$ induction by both IL- $1 \beta$ and TNF $\alpha$ was dose-dependent. However, IL-1 $\beta$ treatment resulted in much higher levels of NF- $\kappa$ B activation. Data shown represent the mean and SD of three separate measurements and are representative of three separate experiments derived from cells from three different brains. $B$, Cells were transfected as above and treated with both IL-1 $(10 \mathrm{ng} / \mathrm{ml})$ and TNF $\alpha(100 \mathrm{ng} / \mathrm{ml})$ in the presence or absence of pretreatment with oATP $(300 \mu \mathrm{M})$. As before, IL-1 and TNF $\alpha$ resulted in induction of NF- $\kappa$ B (with IL-1 induction greater than TNF $\alpha$ induction), and this was downregulated by pretreatment using oATP blockade of $\mathrm{P} 2$ receptors, which had no effect on background levels of $\mathrm{NF}-\kappa \mathrm{B}$ activation. Data shown are the mean and SD of three separate measurements and are representative of three separate experiments with cells from three different brains.

the fold induction over untreated control cultures induced by TNF $\alpha$ was much lower than that induced by IL-1 $\beta$ (Fig. $5 A$ ). Only the maximum dose tested of $\mathrm{TNF} \alpha(100 \mathrm{ng} / \mathrm{ml})$ resulted in activation that was significantly above baseline $(p>0.05)$.

We then tested whether $\mathrm{P} 2$ receptor blockade affected IL- $1 \beta$ - or $\mathrm{TNF} \alpha$-mediated induction of NF- $\kappa \mathrm{B}$ activity. Astrocytes were transfected with the $\mathrm{NF}-\kappa \mathrm{B}$ reporter construct, as above, pretreated with oATP for $2 \mathrm{hr}$, washed, and then activated with either IL-1 $\beta(10 \mathrm{ng} / \mathrm{ml})$ or $\mathrm{TNF} \alpha(100 \mathrm{ng} / \mathrm{ml})$. The data showed that, whereas incubation with oATP alone had no effect on baseline activity of NF- $\kappa \mathrm{B}$, blockade of $\mathrm{P} 2$ receptors significantly downregulated transcriptional activation induced by IL- $1 \beta$ or TNF $\alpha$ (Fig. $5 B$ ). Data for $\mathrm{NF}-\kappa \mathrm{B}$ activation with and without pretreatment with oATP from five different brains are shown in Table 1.

\section{IL-1 $\beta$ and TNF $\alpha$ stimulate NF- $\kappa$ B translocation and DNA binding, which can be downregulated by P2 blockade and nucleotide diphosphate and triphosphate depletion}

Using an EMSA, we then examined the effect of P2 receptor blockade on IL-1 $\beta$ (10 ng)- or TNF $\alpha$ (100 ng)-induced nuclear translocation and binding to an NF- $\kappa \mathrm{B}$ consensus sequence. Astrocytes were stimulated for 30 min with cytokines, and nuclear extracts were prepared. EMSA revealed that, in samples from untreated cells, three mobility shift complexes were detected (data for IL-1 $\beta$ are shown in Fig. 6) that could be competed out with a 50 -fold excess of cold oligonucleotide containing the NF- $\kappa \mathrm{B}$ binding sequence (lanes $N F$ ). As an additional control for specificity, the same extracts were incubated with a nonspecific cold oligonu- 


\begin{tabular}{|c|c|c|c|c|}
\hline Brain \# & Control & $\mathrm{IL}-1 \beta^{b}$ & $\mathrm{oATP}+\mathrm{IL}-1 \beta^{c}$ & Reduction \\
\hline 1 & $61 \pm 6$ & $355 \pm 9$ & $216 \pm 11$ & $48 \%$ \\
\hline 2 & $4 \pm 1$ & $51 \pm 1$ & $17 \pm 2$ & $72 \%$ \\
\hline 3 & $19 \pm 3$ & $187 \pm 25$ & $65 \pm 9$ & $65 \%$ \\
\hline 4 & $69 \pm 7$ & $204 \pm 10.5$ & $139 \pm 9$ & $49 \%$ \\
\hline 5 & $52 \pm 14$ & $294 \pm 24$ & $151 \pm 7$ & $59 \%$ \\
\hline
\end{tabular}

${ }^{a}$ Astrocytes were transfected with a luciferase reporter construct for NF- $\kappa$ B. Cells were harvested at $6 \mathrm{hr}$ after cytokine treatment. Data are expressed as $10^{3} \mathrm{RLU}$. Statistical analysis by Wilcoxon matched paired test demonstrated that inhibition of $\mathrm{NF}-\kappa \mathrm{B}$ transcriptional activation by oATP was statistically significant $(p>0.03)$ over five separate experiments.

${ }^{b}$ Cells were treated with $10 \mathrm{ng} / \mathrm{ml} \mathrm{IL}-1 \beta$.

${ }^{c}$ Cells were pretreated with $300 \mu \mathrm{M}$ oATP.

${ }^{d}$ Calculated as described in Materials and Methods.

cleotide of similar size and guanine and cytosine content (lanes $A P$ ) or a mutant NF- $\kappa \mathrm{B}$ consensus sequence (see below), neither of which affected cytokine-induced shift complexes. IL- $1 \beta$ treatment resulted in the enhancement of the shift complex, labeled $A$. To identify the subunits of the IL- $1 \beta$-induced shift complex, the nuclear extracts were incubated with antibodies to specific subunits of $\mathrm{NF}-\kappa \mathrm{B}$ family proteins (Fig. 6, right panel). Only antibodies to p65 and p50 resulted in the appearance of a supershift in the IL- $1 \beta$ induced complex. This result indicated that the NF- $\kappa \mathrm{B}$ detected was the conventional p65/p50 heterodimer most commonly induced by inflammatory stimuli. TNF $\alpha$ treatment of astrocytes resulted in a much lower level of NF- $\kappa$ B DNA binding compared with IL- $1 \beta$, although again supershift assays indicated induction of p65/p50 heterodimer (data not shown). When nuclear extracts of cells that had been pretreated with oATP before IL- $1 \beta$ stimulation were subjected to EMSA, less NF- $\kappa$ B DNA binding was observed compared with cultures treated with IL- $1 \beta$ alone. Thus, blockade of P2 receptor signaling downregulated IL- $1 \beta$ induction of an NF- $\kappa \mathrm{B}$ mobility shift complex in human astrocytes.

The relatively short incubation period with cytokines needed to demonstrate translocation to the nucleus of NF- $\kappa \mathrm{B}$ allowed us to test the effect of depletion of $\mathrm{P} 2$ receptor ligands from the medium using apyrase, an enzyme that degrades nucleotide triphosphates

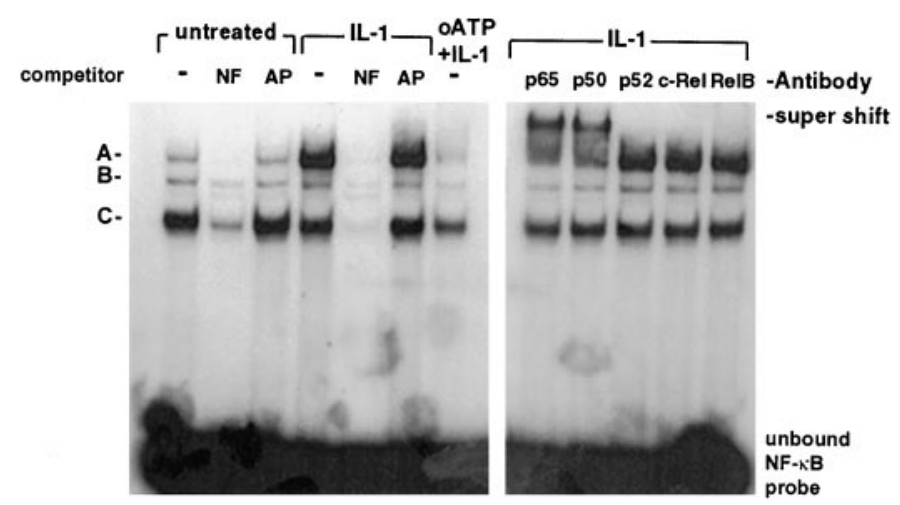

Figure 6. IL- $1 \beta$ induction of $\mathrm{NF}-\kappa \mathrm{B}$ binding is downregulated by blockade of $\mathrm{P} 2$ receptor signaling. Astrocyte cultures were treated with IL-1 $\beta$ in the presence or absence of pretreatment with oATP. Nuclei were harvested at $30 \mathrm{~min}$ and subjected to EMSA with a radiolabeled oligonucleotide probe containing the $\mathrm{NF}-\kappa \mathrm{B}$ binding site along with specific (lane $N F$ ) and nonspecific (lane $A P$ ) competitor oligonucleotides. The left shows control samples, IL- $1 \beta$-treated samples, and IL- $1 \beta$-treated samples after oATP pretreatment. Three shift complexes were observed $(A-C)$ in control cells. Complex A was strongly induced by IL- $1 \beta$ and downregulated by oATP pretreatment. The right panel shows the results of EMSA on IL-1 $\beta$-treated astrocytes incubated with specific antibodies for NF- $\kappa \mathrm{B}$ family members. Only incubation with antibodies to p50 and p65 resulted in the formation of a supershift complex. The experiment shown is representative of four separate experiments using astrocytes derived from four different brains.

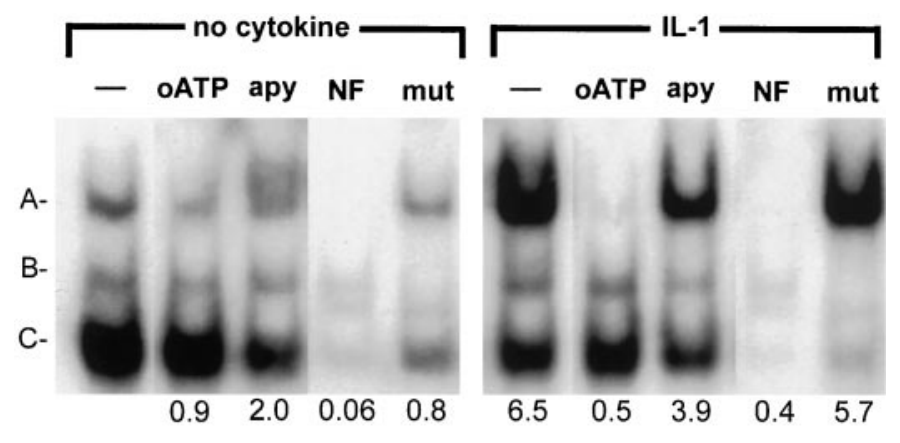

Figure 7. IL-1 $\beta$ induction of NF- $\kappa \mathrm{B}$ binding is downregulated by breakdown of extracellular nucleotides by apyrase. Astrocyte cultures were treated with IL-1 $\beta$ in the presence or absence of apyrase (lane apy; $20 \mathrm{U} / \mathrm{ml}$ ) pretreatment for $30 \mathrm{~min}$ or oATP (lane $O A T P$ ) pretreatment as described previously. Nuclei were harvested at $30 \mathrm{~min}$ and subjected to EMSA with a radiolabeled oligonucleotide probe containing the $\mathrm{NF}-\kappa \mathrm{B}$ binding site along with wild-type (lane NF) and mutant (lane mut) competitor oligonucleotides. Control samples, IL- $1 \beta$-treated samples, and IL- $1 \beta$-treated samples after apyrase pretreatment or oATP are shown. Three shift complexes were observed $(A-C)$ in control cells. Complex A was strongly induced by IL-1 $\beta$ and downregulated by oATP pretreatment, as well as by apyrase. Quantitative analysis of these data is shown below each lane and represents the densitometric ratios for complex A compared with the value for the complex $\mathrm{A}$ in the control sample (left lane). Data shown are representative of two separate experiments with cells from two different brains.

and diphosphates to nucleosides or nucleotide monophosphates. Astrocyte cultures were treated for $30 \mathrm{~min}$ with apyrase before IL-1 $\beta$ stimulation $(10 \mathrm{ng} / \mathrm{ml})$ for $30 \mathrm{~min}$ and nuclear extracts were prepared as above. EMSA showed that treatment with apyrase resulted in a downregulation of IL- $1 \beta$-mediated binding to the $\mathrm{NF}-\kappa \mathrm{B}$ consensus sequence, which could be competed out with 50 -fold excess of cold oligonucleotide, but not one containing a point mutation that abrogates NF- $\kappa \mathrm{B}$ binding (Fig. 7). A similar result was obtained when cells were pretreated with suramin (data not shown). Thus, either blockade of P2 receptors or depletion from the culture medium of nucleotide triphosphates and diphosphates that function as ligands for these receptors resulted in the inhibition of IL- $1 \beta$-stimulated $\mathrm{NF}-\kappa \mathrm{B}$ nuclear translocation and DNA binding, implicating $\mathrm{P} 2$ receptor signaling in the activation of $\mathrm{NF}-\kappa \mathrm{B}$ by IL $-1 \beta$.

\section{IL-1 $\beta$ and TNF $\alpha$ activation of AP-1 are also downregulated by $\mathrm{P2}$ blockade}

In addition to activation of $\mathrm{NF}-\kappa \mathrm{B}$, cytokine stimulation also leads to activation of AP-1, which together with $\mathrm{NF}-\kappa \mathrm{B}$ regulates the inducible expression of many genes involved in the inflammatory response, including NOS II (May and Ghosh, 1998). To determine whether the modulatory effect of $\mathrm{P} 2$ receptor antagonism was specific for activation of $\mathrm{NF}-\kappa \mathrm{B}$, we also transiently transfected primary astrocytes with an AP-1 reporter construct. In human fetal astrocytes, stimulation with either IL- $1 \beta$ or $\mathrm{TNF} \alpha$ induced a dose-dependent activation of AP-1 (Fig. $8 A$ ). IL-1 $\beta$ again provided a stronger stimulus than $\mathrm{TNF} \alpha$ for $\mathrm{AP}-1$ activation, although the fold induction of AP-1 was not as potent as that obtained for $\mathrm{NF}-\kappa \mathrm{B}$, which we ascribe to the higher background activity of AP-1 in these cells. Pretreatment with oATP again led to an inhibition of cytokine-induced activation (Fig. $8 B$ ). A similar effect was observed after pretreatment with suramin (data not shown). Because blockade of $\mathrm{P} 2$ receptors downregulates both NF- $\kappa \mathrm{B}$ and AP-1 activation in response to IL- $1 \beta$ or $\mathrm{TNF} \alpha$, this would imply that signals from $\mathrm{P} 2$ receptor activation interact with common or homologous elements of both IL- $1 \beta$ - and $\mathrm{TNF} \alpha$-mediated signal transduction.

\section{DISCUSSION}

In the normal CNS, the cytokine IL- $1 \beta$ is detected at very low levels and is restricted to specific neuronal elements (Breder et al., 1988), but levels increase dramatically in a number of different inflammatory and degenerative conditions, such as multiple scle- 

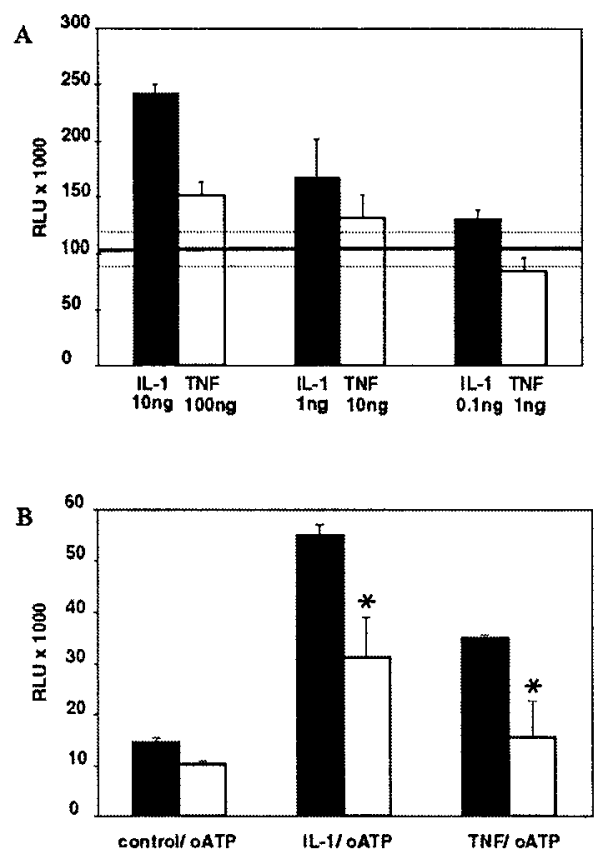

Figure 8. IL- $1 \beta$ and TNF $\alpha$ activation of AP-1 is dose-dependent and downregulated by $\mathrm{P} 2$ receptor blockade. $A$, Astrocyte cultures were transiently transfected with a reporter construct for AP-1 activity. Cells were treated with either IL-1 $\beta(0.1,1$, or $10 \mathrm{ng} / \mathrm{ml})$ or $\mathrm{TNF} \alpha(1,10$, or 100 $\mathrm{ng} / \mathrm{ml}$ ), and luciferase activity was measured in RLU after $4-5 \mathrm{hr}(A)$ Levels of luciferase activity (expressed as RLU) in untreated cells is represented by the transverse line, and SDs of these background levels are demarcated by the dotted lines. AP-1 induction by both IL- $1 \beta$ and TNF $\alpha$ was dose-dependent. However, IL- $1 \beta$ treatment resulted in higher levels of AP-1 activation. $B$, cells were transfected as above and treated with either IL-1 $\beta(10 \mathrm{ng} / \mathrm{ml})$ or TNF $\alpha(100 \mathrm{ng} / \mathrm{ml})$ in the presence or absence of pretreatment with oATP as described above. As before, IL-1 and TNF $\alpha$ resulted in induction of AP-1 (with IL- $1 \beta$ greater than TNF $\alpha$ ) that was downregulated by pretreatment with oATP. Blockade of $\mathrm{P} 2$ receptors with oATP had no effect on background levels of AP-1 activation. Data shown are representative of three separate experiments on cells from three different brains.

rosis and Alzheimer's disease, with expression localized to activated microglia and macrophages. Experiments both in vivo and in vitro have strongly implicated a role for this cytokine in disease pathogenesis in many of these disorders (Rothwell, 1999). The neurodegenerative activities of IL-1 are thought to be attributable to the induction of inflammatory mediators such as the cytokines TNF $\alpha$ and IL-6, as well as toxic factors such as the free radical gas nitric oxide. In cells of human origin, we and others have proposed that astrocytes are an important source of these factors after activation with IL-1 $\beta$ (Liu et al., 1996; Chao et al., 1997). In this study, we now show that the stimulatory effect of IL- $1 \beta$ for astrocytes can be significantly downregulated by blockade of P2 receptors. This inhibition occurred at the level of mRNA accumulation, suggesting that signaling via $\mathrm{P} 2$ receptors regulates elements of the IL-1 $\beta$ signaling cascade, and this was confirmed using specific gene reporter constructs and EMSA for the transcription factors NF- $\kappa \mathrm{B}$ and AP-1. Activation by TNF $\alpha$ was also found to be downregulated by blockade of $\mathrm{P} 2 \mathrm{Y}$ receptors, although this cytokine mediated only a low-level activation of NF- $\kappa \mathrm{B}$ and AP-1. Because astrocytes use $\mathrm{P} 2$ receptor signaling as part of an astrocyte-to-astrocyte communication system (Guthrie et al., 1999), these data provide strong support for the hypothesis that autocrine/paracrine signaling via these receptors regulates astrocyte activation and function in response to changes in the extracellular environment.

That physiologically relevant levels of extracellular ATP are involved in P2 receptor regulation of astrocytic function is supported by the observation that this effect was obtained in the absence of added ligand. In addition, apyrase, an enzyme that catalyzes hydrolysis of extracellular nucleotides, also downregu- lated IL- $1 \beta$-mediated activation of NF- $\kappa$ B. In the CNS, ATP has been identified as a neurotransmitter and would be expected to exist only transiently in the extracellular space because of the activity of ubiquitous ectoATPases (Wang and Guidotti, 1998). However, high levels of extracellular nucleotides are released from sources such as platelets, activated leukocytes, and damaged or dying cells in a number of injurious conditions. Extracellular ATP has been implicated in the induction of a reactive astrogliosis, because in cultured rat astrocytes ATP increases DNA synthesis and cell proliferation (Neary et al., 1998, 1999), induces the release of arachidonic acid metabolites (Bruner and Murphy, 1993; Stella et al., 1997; Brambilla et al., 1999), and induces cytoskeletal changes resulting in process extension (Neary et al., 1994). In most of these studies, activation of members of the P2Y family of receptors has been implicated, and our data are in agreement with this.

Similarly, in the immune system, ATP and its metabolites also modulate the response of cells to inflammatory signals through interactions with $\mathrm{P} 2$ receptors. In human macrophages, ATP has been shown to provide a second stimulus required for the processing and secretion of lipopolysaccharide (LPS)-induced IL-1 $\beta$ (Griffiths et al., 1995; Ferrari et al., 1997a). In these studies, the activation of the $\mathrm{P} 2 \mathrm{X}_{7}$ receptor has been implicated, which results in the formation of a large transmembrane pore that allows the bidirectional passage of molecules up to $900 \mathrm{Da}$ (DiVirgilio, 1995). Activation of this receptor with high levels of ATP (3-15 mM) has also been implicated in the induction of NF- $\kappa \mathrm{B}$ and subsequent cytotoxicity involving both apoptotic and necrotic mechanisms (Surprenant et al., 1996; Ferrari et al., 1997b; von Albertini et al., 1998). We have no evidence from Lucifer yellow permeability assays on ATP-treated cells that this receptor is active in our system (data not shown). In both human and murine macrophages, ATP has also been found to modulate the generation of reactive oxygen intermediates (Schmid-Antomarchi et al., 1997; Sikora et al., 1999) and to regulate LPS-induced NOS II and TNF $\alpha$ expression both in vivo and in vitro (Tonetti et al., 1995; Denlinger et al., 1996; Greenberg et al., 1997; Hu et al., 1998; Sikora et al., 1999). In most of these studies, the action of extracellular nucleotides has been found to be stimulatory and to be dependent on specific agonists. For example, in murine J774 cells, costimulation of cells with LPS plus UTP potently enhanced NOS II expression through a mechanism that involved the activation of a $\mathrm{Ca}^{2+} /$ calmodulindependent protein kinase, whereas ATP only modestly increased NOS II expression (Chen et al., 1998).

In contrast to the primarily proinflammatory activities of nucleotides on immune function, breakdown products of extracellular nucleotides, most notably adenosine, have been shown to have immunomodulatory properties. Some purinergic receptors specific for adenosine have been shown to differentially inhibit macrophage expression of the proinflammatory cytokines $\mathrm{TNF} \alpha$ but have variable effects on IL-6 (Haskó et al., 1996; Sajjadi et al., 1996). In multiple sclerosis patients, in contrast to normal controls, dysregulation of adenosine has been demonstrated and correlated with increased levels of TNF $\alpha$ (Mayne et al., 1999). In addition, adenosine receptor A1 levels were also decreased in multiple sclerosis patients. These studies would suggest that ATP and adenosine have opposing effects on cytokine-stimulated gene expression.

An additional observation made in the course of these studies was that, in human fetal astrocytes, TNF $\alpha$ mediated only a lowlevel activation of NF- $\kappa$ B and AP-1 compared with IL- $1 \beta$. This is in marked contrast to what has been shown in the human monocytic cell lines U937 in which $\mathrm{TNF} \alpha$ has been found to provide a more potent stimulus for proinflammatory gene expression (Nasuhara et al., 1999). Intracellular signaling mediated by IL-1 $\beta$ and TNF $\alpha$ is thought to converge at the level of activation of the MAP kinase kinase kinases involved in the activation of $N F-\kappa B$ and AP-1. Both of these transcription factors have been shown to be required for induction of the human NOS II gene, and multiple $\mathrm{NF}-\kappa \mathrm{B}$ binding sites have been detected in the human NOS II promoter (Marks-Konczalik et al., 1998; Taylor et al., 1998). In our studies, activation of NF- $\kappa \mathrm{B}$ was reduced but not completely down- 
regulated by oATP-mediated $\mathrm{P} 2$ receptor blockade, whereas NOS II expression was completely abrogated by the same concentration of oATP. These data support the concept that threshold levels of $\mathrm{NF}-\kappa \mathrm{B}$ must be achieved for successful induction of transcription of the human NOS II gene and that, in cells activated with TNF $\alpha$ or with IL- $1 \beta$ plus oATP, this threshold level of NF- $\kappa$ B was not reached (Ghosh et al., 1998). Alternatively, NOS II induction may depend on the interaction of multiple transcription factors, including AP-1, that may be differentially affected by purinergic receptor blockade (Marks-Konczalik et al., 1998).

The observation that $\mathrm{P} 2 \mathrm{Y}$ receptor blockade affected both IL- $1 \beta$ and $\mathrm{TNF} \alpha$ activation of $\mathrm{NF}-\kappa \mathrm{B}$ suggests that $\mathrm{P} 2 \mathrm{Y}$ signaling interacts with components of the signal transduction cascade common to both cytokines. In this regard, it is of interest to note that both Neary et al. (1999) and Chen et al. (1998) have observed that signaling via ATP also interacts with the extracellular signalregulated protein kinases ERK1 and ERK2. Together, these data suggest that $\mathrm{P} 2 \mathrm{Y}$ receptor signaling intersects with common or related components of this family of serine/threonine protein kinases (Eder, 1997).

In summary, our results indicate that cross-talk between a P2 receptor signaling pathway and components of the cytokineactivated serine/threonine kinase pathways critically regulates inflammatory gene expression in human fetal astrocytes. Because inflammatory events in the CNS have the potential to cause irreversible damage, mechanisms must exist whereby the cell can appropriately target responses to areas of immune attack, infection, or trauma but spare adjacent uninvolved tissues. The different specificities for endogenous agonists displayed by $\mathrm{P} 2$ receptors suggests that the composition and concentration of nucleotide triphosphates, diphosphates, and monophosphates, as well as nucleosides, in the extracellular space provides the cell with important information concerning changes in the extracellular environment. Furthermore, changes in the expression of these receptors may alter sensitivity to these events. In this regard, it is of interest to note that IL- $1 \beta$ also modifies the functional population of $\mathrm{P} 2 \mathrm{Y}$ receptor on both human and rat astrocytes, resulting in the transient increased expression of a response to UTP, most probably mediated by a P2Y 2 receptor (Stella et al., 1997; John et al., 1999). From these data, we propose that autocrine/paracrine activation of $\mathrm{P} 2$ receptors permits different cell types to communicate with each other, and with the extracellular environment, through the release and sensing of nucleotides such as ATP and to use this information to fine-tune the response to the extent and nature of the injury.

\section{REFERENCES}

Akama KT, Albanese C, Pestell RG, Van Eldik LJ (1998) Amyloid betapeptide stimulates nitric oxide production in astrocytes through an NFkappaB-dependent mechanism. Proc Natl Acad Sci USA 95:5795-5800.

Brambilla R, Burnstock G, Bonazzi A, Ceruti S, Cattabeni F, Abbracchio MP (1999) Cyclo-oxygenase-2 mediates $\mathrm{P} 2 \mathrm{Y}$ receptor-induced reactive astrogliosis. Br J Pharmacol 126:563-567.

Breder CD, Dinarello CA, Saper CB (1988) Interleukin-1 immunoreactive innervation of the human hypothalamus. Science 240:321-324.

Bruner G, Murphy S (1993) Purinergic P2Y receptors on astrocytes are directly coupled to phospholipase A2. Glia 7:219-224.

Burnstock G (1997) The past, present and future of purine nucleotides as signalling molecules. Neuropharmacology 36:1127-1139.

Centemeri C, Bolego C, Abbracchio MP, Cattabeni F, Puglisi L, Burnstock $\mathrm{G}$, Nicosia S (1997) Characterization of the $\mathrm{Ca}^{2+}$ responses evoked by ATP and other nucleotides in mammalian brain astrocytes. Br J Pharmacol 121:1700-1706.

Chao CC, Lokensgard JR, Sheng WS, Hu S, Peterson PK (1997) IL-1induced iNOS expression in human astrocytes via NF-kappa B. NeuroReport 8:3163-3166.

Chen B-C, Chou C-F, Lin W-W (1998) Pyrimidinoceptor-mediated potentiation of inducible nitric-oxide synthase induction in $\mathrm{J} 774$ macrophages. J Biol Chem 273:29754-29763.

Denlinger LC, Fisette PL, Garis KA, Kwon G, Vazquez-Torres A, Simon AD, Nguyen B, Proctor RA, Bertics PJ, Corbett JA (1996) Regulation of inducible nitric oxide synthase expression by macrophage purinoreceptors and calcium. J Biol Chem 271:337-342.

DiVirgilio F (1995) The P2Z purinoceptor: an intriguing role in immunity, inflammation and cell death. Immunol Today 16:524-528.

Dubyak GR, el-Moatassim C (1993) Signal transduction via P2-purinergic receptors for extracellular ATP and other nucleotides. Am J Physiol 265:C577-C606.

Eder J (1997) Tumour necrosis factor alpha and interleukin 1 signalling: do MAPKK kinases connect it all? Trends Pharmacol Sci 18:319-322.

Fam SR, Gallagher CJ, Salter MW (2000) P2Y(1) purinoceptor-mediated $\mathrm{Ca}^{2+}$ signaling and $\mathrm{Ca}^{2+}$ wave propagation in dorsal spinal cord astrocytes. J Neurosci 20:2800-2808.

Ferrari D, Chiozzi P, Falzoni S, Hanau S, DiVirgilio F (1997a) Purinergic modulation of interleukin-1 beta release from microglial cells stimulated with bacterial endotoxin. J Exp Med 185:579-582.

Ferrari D, Wesselborg S, Bauer MKA, Schulze-Osthoff K (1997b) Extracellular ATP activates transcription factor NF-kappaB through the P2Z purinoreceptor by selectively targeting NF-kappa B p65. J Cell Biol 139:1635-1643.

Fujita T, Nolan GP, Liou HC, Scott ML, Baltimore D (1993) The candidate proto-oncogene bcl-3 encodes a transcriptional coactivator that activates through NF-kappa B p50 homodimers. Genes Dev 7:1354-1363.

Ghosh S, May MJ, Kopp EB (1998) NF- $\kappa$ B and Rel proteins: evolutionary conserved mediators of immune responses. Annu Rev Immunol 16:225-260.

Greenberg SS, Zhao X, Wang J-F, Hua L, Ouyang J (1997) cAMP and purinergic P2y receptors upregulate and enhance inducible NO synthase mRNA and protein in vivo. Am J Physiol 273:L967-L979.

Griffiths RJ, Stam EJ, Downs JT, Otterness IG (1995) ATP induces the release of IL-1 from LPS-primed cells in vivo. J Immunol 154:2821-2828. Guthrie PB, Knappenberger J, Segal M, Bennett MVL, Charles AC, Kater SB (1999) ATP released from astrocytes mediates glial calcium waves. J Neurosci 19:520-528.

Haskó G, Szabó C, Németh ZH, Kvetan V, Pastores SM, Vizi ES (1996) Adenosine receptor agonists differentially regulate IL-10, TNF- $\alpha$ and nitric-oxide production in Raw-264.7 macrophages and in endotoxemic mice. J Immunol 157:4634-4640.

Hu Y, Fisette PL, Denlinger LC, Guadarrama AG, Sommer JA, Proctor RA, Bertics PJ (1998) Purinergic receptor modulation of lipopolysaccharide signaling and inducible nitric-oxide synthase expression in RAW 264.7 macrophages. J Biol Chem 273:27170-27175.

John GR, Scemes E, Suadicani SO, Liu JSH, Charles PC, Lee SC, Spray DC, Brosnan CF (1999) IL-1 $\beta$ differentially regulates calcium wave propagation between primary human fetal astrocytes via pathways involving P2 receptors and gap junction channels. Proc Natl Acad Sci USA 96:11613-11618.

King BF, Neary JT, Zhu Q, Wang S, Norenberg MD, Burnstock G (1996) $\mathrm{P} 2$ purinoceptors in rat cortical astrocytes: expression, calcium-imaging and signalling studies. Neuroscience 74:1187-1196.

Lee SC, Liu W, Brosnan CF, Dickson DW (1992) Characterization of primary human fetal dissociated central nervous system cultures with an emphasis on microglia. Lab Invest 67:465-475.

Lee SC, Liu W, Dickson DW, Brosnan CF, Berman JW (1993a) Cytokine production by human fetal microglia and astrocytes. Differential induction by lipopolysaccharide and IL-1 beta. J Immunol 150:2659-2667.

Lee SC, Dickson DW, Liu W, Brosnan CF (1993b) Induction of nitric oxide synthase activity in human astrocytes by interleukin-1 beta and interferon-gamma. J Neuroimmunol 46:19-24.

Liu JSH, Zhao M-L, Brosnan CF, Lee SC (1996) Expression of type II nitric oxide synthase in primary human astrocytes and microglia: role of IL-1beta and IL-1 receptor antagonist. J Immunol 157:3569-3576.

Liu JSH, Amaral TD, Brosnan CF, Lee SC (1998) IFNs are critical regulators of IL-1 receptor antagonist and IL-1 expression in human microglia. J Immunol 161:1989-1996.

Liu W, Shafit-Zagardo B, Aquino DA, Zhao ML, Dickson DW, Brosnan CF, Lee SC (1994) Cytoskeletal alterations in human fetal astrocytes induced by interleukin-1 beta. J Neurochem 63:1625-1634.

Marks-Konczalik J, Chu SC, Moss J (1998) Cytokine-mediated transcriptional induction of the human inducible nitric oxide synthase gene requires both activator protein 1 and nuclear factor kappaB-binding sites. J Biol Chem 273:22201-22208.

May MJ, Ghosh S (1998) Signal transduction through NF-kappa B Immunol Today 19: $80-88$.

Mayne M, Shepel PN, Jiang Y, Geiger JD, Power C (1999) Dysregulation of adenosine A1 receptor-mediated cytokine expression in peripheral blood mononuclear cells from multiple sclerosis patients. Ann Neurol 45:633-639.

Mercurio F, Manning AM (1999) Multiple signals converging on NFkappaB. Curr Opin Cell Biol 11:226-232.

Minden A, Karin M (1997) Regulation and function of the JNK subgroup of MAP kinases. Biochim Biophys Acta 1333:F85-F104.

Murgia M, Hanau S, Pizzo P, Di Virgilio F (1993) Oxidized ATP An irreversible inhibitor of the macrophage purinergic $\mathrm{P} 2 \mathrm{Z}$ receptor. J Biol Chem 268:8199-8203.

Nasuhara Y, Adcock IM, Catley M, Barnes PJ, Newton R (1999) Differential IkappaB kinase activation and IkappaBalpha degradation by interleukin-1beta and tumor necrosis factor-alpha in human U937 monocytic cells. Evidence for additional regulatory steps in kappaB-dependent transcription. J Biol Chem 274:19965-19972.

Neary JT, Baker L, Jorgensen SL, Norenberg MD (1994) Extracellular ATP induces stellation and increases glial fibrillary acidic protein content 
and DNA synthesis in primary astrocyte cultures. Acta Neuropathol (Berl) 87:8-13.

Neary JT, McCarthy M, Kang Y, Zuniga S (1998) Mitogenic signaling from $\mathrm{P} 1$ and $\mathrm{P} 2$ purinergic receptors to mitogen-activated protein kinase in human fetal astrocyte cultures. Neurosci Lett 242:159-162.

Neary JT, Kang Y, Bu Y, Yu E, Akong K, Peters CM (1999) Mitogenic signaling by ATP/P2Y purinergic receptors in astrocytes: involvement of a calcium-independent protein kinase $C$, extracellular signal-regulated protein kinase pathway distinct from the phosphatidylinositol-specific phospholipase C/calcium pathway. J Neurosci 19:4211-4220.

Norenberg MD (1997) Astrocytes. In: Immunology of the nervous system (Keane RW, Hickey WF, eds), pp 173-199. New York: Oxford UP.

Ransom BR, Sontheimer H (1992) The neurophysiology of glial cells. J Clin Neurophysiol 9:224-251.

Rothwell NJ (1999) Annual review prize lecture cytokines-killers in the brain? J Physiol (Lond) 514:3-17.

Sajjadi FG, Takabayashi K, Foster AC, Domingo RC, Firestein GS (1996) Inhibition of TNF- expression by adenosine: role of A3 adenosine receptors. J Immunol 156:3435-3442.

Schmid-Antomarchi H, Schmid-Alliana A, Romey G, Ventura MA, Breittmayer V, Millet MA, Husson H, Moghrabi B, Lazdunski M, Rossi B (1997) Extracellular ATP and UTP control the generation of reactive oxygen intermediates in human macrophages through the opening of a charybdotoxin-sensitive $\mathrm{Ca}^{2+}$-dependent $\mathrm{K}^{+}$channel. J Immunol 159:6209-6215
Sikora A, Liu J, Brosnan C, Buell G, Chessel I, Bloom BR (1999) Cutting edge: purinergic signaling regulates radical-mediated bacterial killing mechanisms in macrophages through a P2X7-independent mechanism. J Immunol 163:558-561.

Stella N, Estelles A, Siciliano J, Tence M, Desagher S, Piomelli D, Glowinski J, Premont J (1997) Interleukin-1 enhances the ATP-evoked release of arachidonic acid from mouse astrocytes. J Neurosci 17:2939-2946.

Surprenant A, Rassendren F, Kawashima E, North RA, Buell G (1996) The cytolytic P2Z receptor for extracellular ATP identified as a P2X receptor (P2X7). Science 272:735-738.

Taylor BS, de Vera ME, Ganster RW, Wang Q, Shapiro RA, Morris SMJ, Billiar TR, Geller DA (1998) Multiple NF-kappaB enhancer elements regulate cytokine induction of the human inducible nitric oxide synthase gene. J Biol Chem 273:15148-15156.

Tonetti M, Sturla L, Giovine M, Benatti U, De Flora A (1995) Extracellular ATP enhances mRNA levels of nitric oxide synthase and TNF $\alpha$ in lipopolysaccharide-treated RAW 264.7 murine macrophages. Biochem Biophys Res Commun 214:125-130.

von Albertini M, Palmetshofer A, Kaczmarek E, Koziak K, Stroka D, Grey ST, Stuhlmeier KM, Robson SC (1998) Extracellular ATP and ADP activate transcription factor NF-kappa B and induce endothelial cell apoptosis. Biochem Biophys Res Commun 248:822-829.

Wang TF, Guidotti G (1998) Widespread expression of ecto-apyrase (CD39) in the central nervous system. Brain Res 790:318-322. 